\title{
Students' Acceptance of Simulation Games in Management Courses: Evidence from Saudi Arabia
}

\author{
Dalal Bamufleh ${ }^{1}$, Reem Hussain ${ }^{1}$, Eman Sheikh ${ }^{1} \&$ Khlood Khodary ${ }^{1}$ \\ ${ }^{1}$ Management Science Department, Yanbu University College, Yanbu, Saudi Arabia \\ Correspondence: Dalal Bamufleh, Management Science Department, Yanbu University College, Yanbu, Saudi \\ Arabia.E-mail: bamuflehd@rcyci.edu.sa
}

Received: May 5, 2020 Accepted: June 7, 2020 Online Published: June 19, 2020

doi:10.5539/jel.v9n4p55 URL: https://doi.org/10.5539/jel.v9n4p55

\begin{abstract}
As a new trend in learning, simulation games play an active and essential role in the area of educational technology. Gaming makes a positive impact on the learning process. It has the capability to enhance creativity, problem-solving, communication, decision-making, and collaboration (Faizan et al., 2015). This paper is aimed at exploring the factors that affect students' acceptance and use of simulation games in management courses. In this study, the unified theory of acceptance and use of technology (UTAUT) is utilized to investigate students' intentions regarding using simulation games for learning. The proposed model and its hypotheses are tested by surveying 115 students at Yanbu University College in Saudi Arabia. Data are gathered and analyzed using smart partial least square. After analysis, the results prove that performance expectancy, effort expectancy, and social influence have positive effects on behavioral intentions (BI) and that facilitating conditions have a positive impact on use behavior (UB). In addition, a positive effect is found between BI and UB. The authors utilize the study findings to highlight some recommendations that could improve the implementation of simulation games. Finally, future studies are recommended to increase the sample size for more reliable results and conclusions.
\end{abstract}

Keywords: simulation-based learning, simulation games, UTAUT

\section{Introduction}

Games and simulations are being used increasingly in the academic and business fields to enhance the learning process (Costin, O'Brien, \& Slattery, 2018). Business simulation games are one of the learning tools that have emerged in the past few years. "It has now been nearly 40 years since the first known use of a business simulation game in a university class" (Faria \& Nulsen, 2014). Simulations are defined as artificial environments created to manage individual experiences of reality (Bell, Kanar, \& Kozlowski, 2008). One of the most critical features of simulations is the ability to increase, replace, create, and/or manage an actual learner experience to reflect the real world by providing realistic learning content and features (Cannon-Bowers \& Bowers, 2009). The value of using simulation games is to give students the chance to practice their knowledge and develop certain skills such as leadership, strategic decision-making, and effective communication and to enjoy good collaboration and a collective sense of responsibility (Li \& Dong, 2009).

Simulation games are related to a significant concept called e-learning. According to the literature, e-learning is known by multiple terms, including computer-assisted instruction, web-based learning, distributed learning, online learning, or internet-based learning. There are two styles of e-learning. The first is computer-assisted instruction, which "uses computers to aid in the delivery of standalone multimedia packages for teaching and learning," and the second is distance learning, which "uses information technologies to deliver instruction to remote learners from a central site" (Tan, 2013). The application of technology in the educational field is a difficult multilateral process that involves not only the presence of technology but also the development of teacher skills and long-term funding (Mădălina, Dedu, \& Deaconu, 2017).

Based on the authors' observation, most of the participating students faced some issues in accepting a game-based assessment called Capsim that was required to complete a management course entitled Business Policy at Yanbu University College, Saudi Arabia. Capsim was designed in 1985 by its founder Dan Smith for developing programs and simulation games to support the needs of business educators around the world. It is a simple self-simulation game that offers a unique, realistic opportunity for students to experience business strategy on a global stage (“About Capsim," 2017). 


\subsection{Significance of the Study}

This research makes theoretical as well as practical contributions. From the theoretical perspective, the study validates the unified theory of acceptance and use of technology (UTAUT) model for demonstrating and predicting students' behavior regarding, and acceptance of, simulation/game-based learning. Thus, the paper contributes to technology adoption and acceptance literature in the domain of simulation-based learning. Besides, according to the authors' knowledge, this is the first study in the context of simulation-based learning adoption and acceptance in Saudi universities. From the practical perspective, the results show that performance expectancy (PE), effort expectancy (EE), social influence (SI), and facilitating condition (FC) influence students' intention to use simulation games in management courses. Finally, the study delivers some insights to teachers and universities hosting simulation-based learning, which will help them improve students' acceptance of such a learning style.

\subsection{Research Objectives}

This paper is aimed at determining the factors that affect students' acceptance of using new technology in learning management courses. Therefore, the question of this study is, "What are the factors that affect students' acceptance and use of simulation games in management courses?" Finding these factors will help to provide recommendations that would improve simulation-based learning implementation. In addition, the study results would contribute to enhancing students' acceptance of such a learning strategy to ensure efforts and funds invested in said method do not go to waste. As mentioned earlier, the scope of this research paper covers a management course entitled Business Policy (MGT 418) on the female campus of Yanbu University College.

\section{Review of Related Literature}

In the following subsections of this literature review, the authors will first provide sufficient definitions of e-learning and its benefits. Second, simulation-based learning will be defined, and its types discussed. Thereafter, game-based learning will be explained in the third subsection with definitions and examples of simulation games implemented in many fields. Finally, the fourth subsection will contain a discussion of the user acceptance models and their definitions, constructs, authors, and years of establishment. The resources that have been used to prepare and write this literature review are journals, books, and research papers from research websites such as Science Direct, SAGE Journals, and ERIC: Education Resources Information Center.

\subsection{E-Learning}

Nowadays, technologies are used widely in educational fields to improve the learning process. Furthermore, based on continuous changes in students' needs and the increased competition among organizations for further development and success, the need to implement e-learning to generate educational and economic value has also deepened. Therefore, the integration of e-learning into educational routines to support continuous learning and teaching processes has become a challenge for most organizations.

E-learning can be defined as "a form of online learning that occurs in a formal context with the use of multimedia technologies" (Anderson, 2016). It is also the use of internet technologies to enhance knowledge and performance (Ruiz, Mintzer, \& Leipzig, 2006). Additionally, e-learning is known as a system that employs technology in the shape of computers, multimedia devices, and the internet to enhance the usual classroom interactions between teachers and students (Al-Juda, 2017). It is further defined as "the employment of information and communication technologies to support the development and delivery of learning in academic and professional development institutions" (Yusuf \& Al-Banawi, 2013). In other words, it is "a concept that focuses on the use of digital technologies in education" (Fischer, Heise, Heinz, Moebius, \& Koehler, 2014).

E-learning is growing exponentially in the educational field. One of the main reasons for its rise in colleges and universities is their desire to generate new revenue streams, improve access, and provide students with the greatest flexibility in learning (Bell \& Federman, 2013). It promotes active, cheaper, and faster learning processes because it caters to many knowledge and skill levels and is available anytime, anywhere. E-learning employs electronic technologies to access educational resources that provide students with the means to solve problems, develop skills, and collaborate productively in groups instead of the traditional way of learning (Cooper \& Mueck, 1990). It is also seen to reduce the cost of education and improve access to quality teaching (Laurillard, 2007). E-learning has become a phenomenon that is difficult to ignore, particularly in the educational sector (Yusuf \& Al-Banawi, 2013).

\subsection{Simulation-Based Learning}

The traditional approaches to learning, such as lecturing, have their limits such as lack of experience in real-life situations and the understanding of the concept being insufficient for the world of work (MacKay \& McKiernan, 
2004). These limitations can be resolved by new technologies such as simulation-based learning (Adobor \& Daneshfar, 2006; Aranda, 2007). Because e-learning teaches learners using technological means, simulation-based learning falls under e-learning in that it utilizes simulations by mimicking real-world situations. Simulation-based learning techniques seek to mimic a system, phenomenon, entity, or process. "These techniques attempt to represent or predict aspects of the behavior of the problem or issue being studied" (Lean, Moizer, Towler, \& Abbey, 2006). Simulations can allow the experiments to be conducted within imaginary situations to reflect the actual nature and outcomes of potential conditions. Moreover, simulation is a technique for training and practice and can be applied in many disciplines and for many trainees.

Simulations first appeared in many areas such as anesthesia, aviation, military training, space flight, and nuclear power generation. In the 1980s, the usage of simulation-based learning increased because of the low cost of personal computers and the availability of simulation programs. The cost of simulations was initially high, and they were available only in a select few institutions in which they were viewed as a valuable long-term investment. Indeed, simulation-based learning has become a form of flexible and constant education and training (Lateef, 2010). It has been widely applied in numerous fields. Above all, simulations help greatly in mitigating errors and maintaining safety, especially in industries with no tolerance of any deviation from the specified standards (Gaba, 2004).

Simulation games can take different directions depending on the actions of their players, their reactions, and natural complications that arise while playing. Simulation games involve handling evolving multidimensional problems; have playing times ranging from 50 minutes to many days; and use role descriptions, including goals, constraints, background information, and responsibilities (Gredler, 2004). Two general types of simulation differ according to participants' roles and interaction with the situation. These two types are experiential and symbolic simulations. Experiential simulations: This type has been developed to allow the learners to interact in situations that could be too expensive or dangerous to be enacted in the real world (Gredler, 2004) (for example, training medical students in a safe environment with no potential harm to patients) (Yeun, Bang, Ryoo, \& Ha, 2014). Symbolic simulations: This type has been developed and implemented based on the increased capabilities of computers in recent years. "It is a dynamic representation of the functioning or behavior of some universe, system, or set of processes or phenomena by another system, in this case, a computer" (Gredler, 2004). One of the essential characteristics that define this type is that the student acts as a researcher or investigator and tests his or her theory of the relationships among the variables in the system. This feature is a significant difference between symbolic and experiential simulations.

That said, some earlier researchers identified three specific types of simulation-based learning: role play, gaming, and computer simulation (Feinstein, Mann, \& Corsun, 2002; Hsu, 1989). Each type has a different composition and different utility.

In a role-playing exercise, participants act out the role of a character in a particular situation following a set of rules and interacting with other role players. Role play might also be non-interactive, for example, in the case of presentations where students adopt a particular character role. With gaming, the key elements entail interaction within a predetermined context, often involving forms of competition, cooperation, conflict, or collusion. These interactions are constrained by set rules and procedures. Finally, computer simulations aim to replicate system characteristics using mathematics or simple object representations (Feinstein et al., 2002).

"The most substantive studies to date relate to the use of computer-based simulation games in business education" (Lean et al., 2016). Many studies regarding the use of simulation games in U.S. schools of business were reviewed by Faria and Wellington (2004). Their study revealed that the rate of schools employing simulation games increased from $71.1 \%$ at the beginning of the 1960s (Dale \& Klasson, 1962) to $97.5 \%$ by 1998 (Faria, 1998). Faria and Wellington's 2004 investigation was focused on the employment of simulation games by individual academics. The results demonstrated that $30.6 \%$ of the 1085 respondents were existing simulation game users, while $17.1 \%$ were prior users, and $52.3 \%$ had never used simulation games for teaching business.

Game-based learning is part of simulation-based learning. Games have become an attractive and motivational tool to use in the education field thanks to technological advances (Garris, Ahlers, \& Driskell, 2002). Game-based learning is focused on learning outcomes to link the efficiency of learning basics to game environments. Game-based learning is aimed at developing self-confidence and problem-solving skills in learners (Liang, Lee, \& Chou, 2010). Prensky and Prensky (2007) defined game-based learning as a joyful pursuit that engages users and combines meaningful education with interactive entertainment to create a new and exciting medium.

Game-based learning has several game types, of which the most common are flight simulations in PC games and 
simulators for NASA training (Salas, Wildman, \& Piccolo, 2009). In addition, a commercial PC-based management simulation game is available called Bank President; created by Lewis Lee, the game allows students to manage banking activities online with other team members (Koppenhaver, 1993).

One of the known simulation games is Capsim. It is a simple self-simulation game that provides a realistic experience allowing students to learn how to run a business in the real world by making decisions about finance, research and development, and marketing departments based on simulated information (Costin et al., 2018). It enables students to experience how to run a small business in reality. Finally, the purpose of the game is to improve the students' performance and enhance their attitude, skills, and knowledge, which will eventually benefit the organization they go on to work for (Salas et al., 2009).

Another well-known example is the Innov8 game, one of the serious games that were developed by IBM ${ }^{\circledR}$ as part of its academic initiative program and usually used by educational institutions to enhance their business processes. The game involves a first-person role-playing approach wherein the player is a consultant within an organization that is experiencing challenges (Roodt \& Joubert, 2009.). In addition, the game has two primary objectives, the first of which is teaching those from a more technical background about business procedures and more particularly about business process management, whereby the players interact with other virtual employees while engaging in their daily activities in an imaginary company called After, Inc. (Lali, 2008); the second is immersing them in a tridimensional world closely aligned to real-life scenarios (Roodt \& Joubert, 2009) Another example of game-based simulation is Practice Operations from McGraw-Hill Education. Practice Operations is an interactive, 3-D simulation game that allows students to manage the operations of a clothing manufacturing and distribution company. The game contains several modules that focus on dealing with issues concerning the production process, capacity, supply chain, Just-In-Time (JIT), labor management, order fulfillment, customer satisfaction, and quality control (Practice Operations, n.d.).

The benefits of learning through games are numerous, including bringing students closer to simulating real-life experiences than can be achieved with traditional educational media, thus generating a lack of fear of real-life consequences (Mann et al., 2002). The most important benefits are problem-solving, critical thinking, decision-making, and collaboration (Binkley et al., 2012). Moreover, the games offer students the chance of learning new skills to be productive in society (Kim \& Shute, 2015).

\subsection{User Acceptance Models}

Besides all the advantages of simulation-based learning, it is vital to possess a better understanding of why people resist or accept using technology so as to create suitable theories/models for evaluating new technologies, predicting how the user will respond to them, and improving the way users accept the technology (Swanson, 1974). Therefore, acceptance can be measured by understanding behavior which explains whether a user can accept or reject a new situation (Halili, Sulaiman, \& Abdul Razak, 2017). In the following subsections, user acceptance models are discussed in detail to identify a suitable model for this study.

\section{Theory of Reasoned Action (TRA) (1975)}

Theory of reasoned action (TRA) is a model that explains how an individual is going to behave as influenced by intentions and past behaviors and actions (Halili et al., 2017). It was established by Martin Fishbein and Icek Ajzen in 1975. The main goal of the TRA model is to predict and understand an individual's behavior (Thrasher, Andrew, \& Mahony, 2007). TRA is one of the primary models designed by social psychologists to study intended behaviors (Fishbein \& Ajzen, 1975). This theory has three general constructs, which are: behavioral intentions, attitudes, and subjective norms (Sharma \& Mishra, 2014). Behavioral intentions refer to the "function of both attitudes toward behavior and subjective norms toward that behavior which has been found to predict actual behavior." Attitudes are the "sum of beliefs about a particular behavior weighted by evaluations of these beliefs." Finally, subjective norms denote the "influence of people in one's social environment on his behavioral intentions; beliefs, weighted by the importance one attributes to each of their opinions that will influence one's behavioral intention" (Fishbein \& Ajzen, 1975).

\section{Social Cognitive Theory (SCT) (1986)}

Albert Bandura $(1978,1989)$ developed social cognitive theory (SCT) in 1986 by assuming that learning occurs where observations are made through social resources. In other words, humans learn through what they watch and then choose to mimic, mutate, or disregard the observed actions. Moreover, SCT gives notable explanations for one's behavior form both personal cognition and social environment aspects (Lin \& Huang, 2008). The theory outlines a few crucial factors that influence behavior. The first factor is outcome expectations - performance, which is "the performance-related consequence of the behavior. Specifically, 
performance expectations address job-related outcomes" (Bandura, 1986). Second is outcome expectations - personal, which refers to "the personal consequence of the behavior. Specifically, personal expectations address the individual esteem and sense of accomplishment" (Bandura, 1986). The third factor is self-efficacy, which is the "judgment of one's ability to use technology to accomplish a particular job or task" (Bandura 1986). Fourth is affect, which is defined as "an individual's liking for a particular behavior" (Bandura, 1986). Finally, anxiety involves "evoking anxious or emotional reactions regarding performing a behavior" (Bandura, 1986; Compeau \& Higgins, 1995).

\section{Technology Acceptance Model (TAM) (1989)}

In 1989, Davis introduced the technology acceptance model (TAM), defined as a theory of information system that explains how users will accept or reject a new technology. TAM provides the factors that are verified to explain users' technology acceptance behavior across a broad range of end-user computing technologies and user populations (Davis, Bagozzi, \& Warshaw, 1989). The model has two core constructs: perceived usefulness and perceived ease of use. First, perceived usefulness refers to "the degree to which a person believes that using a particular system would enhance his or her job performance" (Tan, 2013). Second, perceived ease of use means "the degree to which a person believes that using a particular system would be free of effort" (Tan, 2013). TAM has also, been expanded into the extended technology acceptance model (TAM2), for which more constructs have been added, namely subjective norms, image, output quality, and result demonstrability (Venkatesh \& Davis, 2000). Subjective norms are defined as a "person's perception that most people who are important to him think he should or should not perform the behavior in question" (Fishbein \& Ajzen, 1975). Image is referred to as "the degree to which use of an innovation is perceived to enhance one's image or status in one's social system" (Moore \& Benbasat, 1991). Output quality is identified as the "tasks a system is capable of performing and the degree to which those tasks match their job goals or job relevance, people will take into consideration how well the system performs those tasks" (Venkatesh \& Davis, 2000). Job relevance means "an individual's perception regarding the degree to which the target system is applicable to his or her job" (Venkatesh \& Davis, 2000). This factor is regarded as a cognitive judgment that exerts a direct effect on perceived usefulness, distinct from social influence processes (Sharma \& Mishra, 2014). Finally, result demonstrability is defined as the "tangibility of the results of using the innovation" (Moore \& Benbasat, 1991). This implies that users can be expected to shape more positive ideas of system usefulness if they can determine the link between the system uses and the positive results (Sharma \& Mishra, 2014).

In addition, the updated model includes two moderating variables that affect subjective norms' relationship with perceived usefulness and intention to use. The variables are experience and voluntariness (Venkatesh \& Davis, 2000). Voluntariness refers to "the extent to which potential adopters perceive the adoption decision to be non-mandatory" (Agarwal \& Prasad, 1997). TAM2 suggests that subjective norms affect a user's intention to use the new technology only if the system usage is mandatory and the user has low experience of using such technology. Similarly, experience moderates subjective norms' relationship with perceived usefulness. In other words, users who have directly experienced using the technology are less affected by social information when using it and can determine the technology's perceived usefulness (Venkatesh \& Davis, 2000).

\section{Theory of Planned Behavior (TPB) (1991)}

Theory of planned behavior (TPB), created by Ajzen in 1991, is an extended version of TRA. The main factor of this model is based on the intention of humans to implement such behavior. TPB refers to the study of predicting an individual's attitude or behavior and explaining an individual's behavior. TPB has three core constructs adapted from TRA, which are attitude toward behavior, subjective norms, and perceived behavioral control. First, attitude toward behavior, adopted from TRA, refers to "an individual's positive or negative feelings (evaluative effect) about performing the target behavior" (Tan, 2013). Additionally, it means how a person is feeling about engaging in a specific behavior. Second, subjective norms are "the person's perception that most people who are important to him think he should or should not perform the behavior in question" (Tan, 2013). The third factor, perceived behavioral control, is defined as "the perceived ease or difficulty of performing the behavior" (Tan, 2013).

\section{Model of Personal Computing Utilization (MPCU) (1991)}

Thompson, Higgins, and Howell (1991) explained PC utilization behavior according to the model of personal computing utilization (MPCU), according to which "Behavior is determined by what people would like to do (attitudes), what they think they should do (social norms), what they have usually done (habits), and by the expected consequences of their behavior" (Thompson et al., 1991). Moreover, six factors have been identified as pertaining to technology acceptance in this model. First, job fit is "the extent to which an individual believes that 
using technology can enhance the performance of his or her job." Second is complexity, which refers to "the degree to which an innovation is perceived as relatively difficult to understand and use." The third factor is long-term consequences, which are the "outcomes that have a pay-off in the future." Fourth is affect towards use, which is defined as "the feelings of joy, elation, or pleasure, or depression, disgust, displeasure, or hate associated use by an individual with a particular act." Fifth, social factors relate to the "individual's internalization of the reference group's subjective culture and specific interpersonal agreements that the individual has made with others, in specific social situations." Finally, facilitating condition refers to the fact that the "provision of support for users of PCs may be one type of facilitating condition that can condition influence system utilization" (Thompson et al., 1991).

\section{Motivation Model (MM) (1992)}

The motivation model (MM), applied by Davis et al., posits that human behavior is based on two factors, which are intrinsic and extrinsic motivation (Davis, Bagozzi, \& Warshaw, 1992; Vallerand, 1997). Extrinsic motivation is "the perception that users will want to perform an activity because it is perceived to be instrumental in achieving valued outcomes that are distinct from the activity itself, such as improved job performance, pay, or promotions," while intrinsic motivation is "the perception that users will want to perform an activity for no apparent reinforcement other than the process of performing the activity per se" (Davis et al., 1992).

\section{Combined TAM and TPB (C-TAM-TPB) (1995)}

Combined TAM and TPB (C-TAM-TPB) is a combination of these two different modules introduced by Taylor and Todd in 1995. This model has three primary constructs, which are attitude, normative, and control beliefs, in addition to perceived usefulness and perceived ease of use. These constructs have been defined previously in the TAM and TPB models. Understanding these factors will ensure the effectiveness of IT resources in the organization (Davis, 1989; Mathieson, 1991).

\section{Innovation Diffusion Theory (IDT) (1995)}

Innovation diffusion theory (IDT) explains the method by which users become familiar with technological advances (Rogers, 1995). Established by Everett M. Rogers in 1995, it represents the method of accepting or rejecting an innovation. According to this model, five constructs/traits encourage a person to like new technology and influence his/her decisions on using it: relative advantage, compatibility, complexity, trialability, and observability. First, relative advantage refers to "the degree to which an innovation is perceived to be better than the idea it supersedes." Second, compatibility means "the degree to which an innovation is perceived as consistent with the existing values, past experiences, and needs of potential adopters." Third, complexity defines "the degree to which an innovation is perceived as relatively difficult to understand and use." Fourth, trialability is "the degree to which an innovation may be experimented with on a limited basis." Finally, observability refers to "the degree to which the results of an innovation are visible to others" (Rogers, 1995).

The Unified Theory of Acceptance and Use of Technology (UTAUT) (2003)

UTAUT was established by Viswanath Venkatesh, Michael G. Morris, Gordon B. Davis, and Fred D. Davis in 2003. It is a user acceptance model constructed from eight models and theories: TRA, TAM, MM, TPB, C-TAM-TPB, MPCU, IDT, and SCT. UTAUT was formulated to combine the multiple theories on individual acceptance of information technology into a consolidated theoretical model (Venkatesh et al., 2003). UTAUT is intended to serve as a full model that can be utilized across a range of applications (Sharma \& Mishra, 2014). This theory is intended to be one of the best models because it can demonstrate up to $70 \%$ of the variance, while the previous theories demonstrated only up to $30 \%-40 \%$ variance in the adoption behavior (Venkatesh et al., 2003). This theory has four primary constructs, which are PE, EE, SI, and FC. First, PE is defined as "the degree to which an individual believes that using the system will help him or her to attain gains in job performance." Second, EE refers to "the degree of ease associated with the use of the system." Third, SI defines "the degree to which an individual perceives that important others believe he or she should use the new system." The last construct is FC, which refers to "the degree to which an individual believes that an organizational and technical infrastructure exists to support the use of the system" (Venkatesh et al., 2003). Besides these constructs, this model has four moderating variables: age, gender, experience, and voluntariness of use (Attuquayefio \& Addo, 2014). 
Table 1. Review of user acceptance models

\begin{tabular}{|c|c|c|}
\hline Year & Model $\backslash$ Theory & Constructs/Determinants of Adoption \\
\hline 1975 & Theory of reasoned action (TRA) (Fishbein \& Ajzen, 1975) & $\begin{array}{l}\text { Behavioral intentions and its antecedents, attitudes, and } \\
\text { subjective norms }\end{array}$ \\
\hline 1986 & Social cognitive theory (SCT) (Bandura, 1986) & $\begin{array}{l}\text { Outcome expectations-performance, outcome } \\
\text { expectations-personal, self-efficacy, affect, anxiety }\end{array}$ \\
\hline 1989 & Technology acceptance model (TAM) (Davis, 1989) & Perceived usefulness, perceived ease of use \\
\hline 1991 & Theory of planned behavior (TPB) (Ajzen, 1991) & $\begin{array}{l}\text { Attitude toward behavior, subjective norms, perceived } \\
\text { behavioral control }\end{array}$ \\
\hline 1991 & The model of PC utilization (MPCU) (Thompson et al., 1991) & $\begin{array}{l}\text { Job fit, complexity, long-term consequences, affect toward } \\
\text { use, social factors, facilitating conditions }\end{array}$ \\
\hline 1992 & The motivation model (MM) (Davis et al., 1992) & Extrinsic motivation, intrinsic motivation \\
\hline 1995 & Combined TAM and TPB (C-TAM-TPB) (Taylor \& Todd, 1995) & Attitude, normative, control beliefs, perceived usefulness \\
\hline 1995 & Innovation diffusion theory (IDT) (Rogers, 1995) & $\begin{array}{l}\text { Relative advantage, compatibility, complexity, trialability, } \\
\text { observability }\end{array}$ \\
\hline 2003 & $\begin{array}{l}\text { The unified theory of acceptance and use of technology } \\
\text { (UTAUT) (Venkatesh et al., 2003) }\end{array}$ & $\begin{array}{l}\text { Performance expectancy, effort expectancy, social influence, } \\
\text { facilitating conditions }\end{array}$ \\
\hline
\end{tabular}

\section{Method}

In this section the authors outline the model development and constructs utilized in this study. In addition, they address the research method, hypotheses, and data collection instrument that have been used. The UTAUT model has been modified and applied to study the factors that affect the acceptance and use of the Capsim simulation game by Yanbu University College (YUC) female campus students. The course that applies the simulation game at YUC is entitled Business Policy, which is designed for undergraduate students to learn various issues in business strategies. It is a core course for management information system, human resources, and accounting students.

A quantitative research method that includes a questionnaire survey was used to conduct an interpretive study. The survey questions were derived from the constructs of the UTAUT model: PE, EE, SI, FC, behavioral intention (BI), and use behavior (UB). The questions were of two types, one being on a 5-point Likert-type scale serving to measure the level of students' agreement $(1=$ strongly disagree, $2=$ disagree, $3=$ neutral, $4=$ agree, 5 = strongly agree), and the other being open-ended questions. The survey was conducted in an online format. The number of students who participated in the survey was 115. The authors relied on the UTAUT model for many reasons. First, as mentioned earlier, the UTAUT model was constructed from eight theories and models to make an integrated theoretical model to serve and test the acceptance of information technology by individuals (Venkatesh et al., 2003). Second, this model was constructed as a complete model to serve a wide range of applications (Sharma \& Mishra, 2014). Third, it is one of the superior models because it can explain $70 \%$ of the variance, while the acceptance models before 2003 explained only $30 \%-40 \%$ of the variance in the adoption behavior (Venkatesh et al., 2003).

\subsection{Research Model}

Based on the UTAUT model, four key factors influence the students' use and acceptance of the Capsim simulation game: PE, EE, SI, and FC. However, the authors made some modifications to the model because moderators (age, gender, experience, and voluntariness of use) do not affect this study. It was conducted at the female campus only for students in the same age group, which makes the gender and age variables irrelevant. In addition, the experience and voluntariness of use variables were excluded because students at YUC had never experienced simulation games before such a course, and Capsim is required to complete the course. Figure 1 presents the research model as well as the proposed hypotheses. 


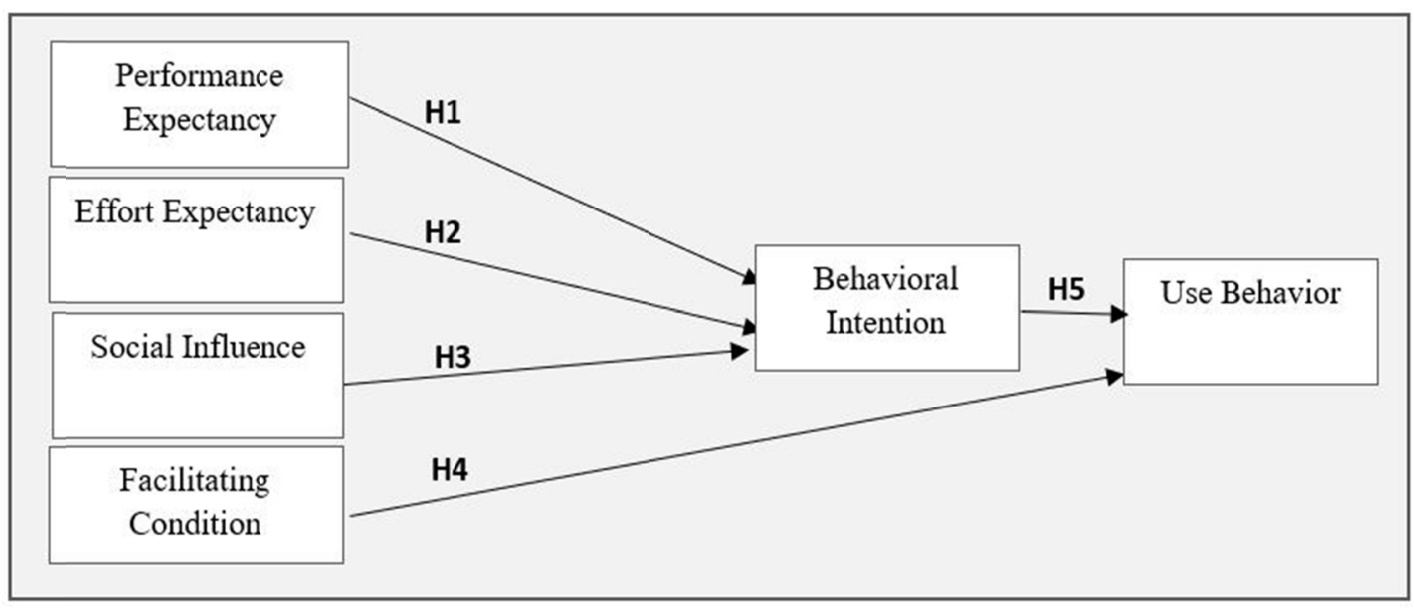

Figure 1. The proposed model

\subsection{Hypotheses}

The authors hypothesized relationships between variables as follows:

H1- There would be a significant positive relationship between PE and BI when using the Capsim simulation game.

H2- There would be a significant positive relationship between EE and BI when using the Capsim simulation game.

H3- There would be a significant positive relationship between SI and BI when using the Capsim simulation game.

H4- There would be a significant positive relationship between FC and UB when using the Capsim simulation game.

H5- There would be a significant positive relationship between BI and UB when using the Capsim simulation game.

To implement the hypotheses, the UTAUT model was modified according to the scope of this study. PE can be defined in the context of the study as the degree to which the Capsim game is useful to students in terms of achieving the expected learning outcomes. EE is the degree to which the Capsim game is easy to use and understand. SI is defined as the degree to which others' opinions (teachers and other students) influence the students to use the Capsim game. Finally, FC measures the extent to which the college provides technical support to students to complete the game. Table 2 shows the questions of the UTAUT model that were provided to the students in the survey. Besides these questions, demographic questions were also included in the survey. Furthermore, two open-ended questions were asked to the students to help the authors draw conclusions. 
Table 2. Survey items

\begin{tabular}{|c|c|c|}
\hline Construct & Question Description & Reference \\
\hline $\begin{array}{l}\text { Performance } \\
\text { Expectancy } \\
\text { (PE) }\end{array}$ & $\begin{array}{l}\text { PE1: I find using the simulation game applied in the management course (MGT 418) is useful to my } \\
\text { study. } \\
\text { PE2: Using the simulation game applied in the management course (MGT 418) increases my } \\
\text { performance in my learning activities. } \\
\text { PE3: Using the simulation game applied in the management course (MGT 418) improves my } \\
\text { learning results. } \\
\text { PE4: Using the simulation game applied in the management course (MGT 418) enhances my } \\
\text { learning motivation. }\end{array}$ & $\begin{array}{l}\text { Venkatesh et al., } \\
2003\end{array}$ \\
\hline $\begin{array}{l}\text { Effort } \\
\text { Expectancy } \\
\text { (EE) }\end{array}$ & $\begin{array}{l}\text { EE1: My interaction with the simulation game applied in the management course (MGT 418) is } \\
\text { clear and understandable. } \\
\text { EE2: It is easy for me to become skilled at using the simulation game applied in the management } \\
\text { course (MGT 418). } \\
\text { EE3: I find it easy to use the simulation game applied in the management course (MGT 418). } \\
\text { EE4: Learning to operate the simulation game applied in the management course (MGT 418) is } \\
\text { easy for me. }\end{array}$ & $\begin{array}{l}\text { Venkatesh et al., } \\
2003\end{array}$ \\
\hline $\begin{array}{l}\text { Social } \\
\text { Influence (SI) }\end{array}$ & $\begin{array}{l}\text { SI1: People who influence my behavior think that I should use the simulation game applied in the } \\
\text { management course (MGT 418). } \\
\text { SI2: Professors in my institution have been helpful in the use of the simulation game applied in the } \\
\text { management course (MGT 418). } \\
\text { SI3: People who are important to me think that I should use the simulation game applied in the } \\
\text { management course (MGT 418). } \\
\text { SI4: In general, I have been supported to use the simulation game applied in the management course } \\
\text { (MGT 418). }\end{array}$ & $\begin{array}{l}\text { Venkatesh et al., } \\
2003\end{array}$ \\
\hline $\begin{array}{l}\text { Facilitating } \\
\text { Conditions } \\
\text { (FC) }\end{array}$ & $\begin{array}{l}\text { FC1: I have the resources necessary to use/play the simulation game applied in the management } \\
\text { course (MGT 418). } \\
\text { FC2: I have the knowledge necessary to use/play the simulation game applied in the management } \\
\text { course (MGT 418). } \\
\text { FC3: I think that using a business simulation game fits well with the way I like to learn. } \\
\text { FC4: If I have problems using the simulation game, I could solve them very quickly. }\end{array}$ & $\begin{array}{l}\text { Venkatesh et al., } \\
2003\end{array}$ \\
\hline $\begin{array}{l}\text { Behavioral } \\
\text { Intention (BI) }\end{array}$ & $\begin{array}{l}\text { BI1: I predict I would use a business simulation game in my future learning activities. } \\
\text { BI2: I plan to use a business simulation game in my future learning activities. } \\
\text { BI3: I intend to use a business simulation game in my future learning activities. } \\
\text { BI4: I would use a business simulation game to improve my management learning. } \\
\text { BI5: I feel that working with this simulation game is a good idea. }\end{array}$ & $\begin{array}{l}\text { Venkatesh et al., } \\
2003\end{array}$ \\
\hline $\begin{array}{l}\text { Use Behavior } \\
\text { (UB) }\end{array}$ & $\begin{array}{l}\text { UB1: I use the simulation game when learning the MGT } 418 \text { course. } \\
\text { UB2: I use the simulation game to visualize how business concepts learned in the MGT } 418 \text { class } \\
\text { could be applied in real business scenarios. } \\
\text { UB3: I use the simulation game to visualize the possible complexity in real business scenarios. }\end{array}$ & $\begin{array}{l}\text { Venkatesh et al., } \\
2003\end{array}$ \\
\hline
\end{tabular}

\section{Data Analysis and Discussion}

Partial least square (PLS)-based structural equation modeling was used in this study for analyzing the survey data. This model can simultaneously test the structural and the measurement models to give complete analysis of the inter-relationships. The Smart PLS Version 3.0 and the two-step analysis approach were used to analyze the obtained data. The survey contained the following demographic data: level, major, and experience of simulation-based game use. Table 3 shows the frequency and percentage of each of them. This section of the research paper includes two parts; the first section is the assessment of the measurement model, followed by the second section, which is the assessment of the structural model. 
Table 3. Demographic data of the survey

\begin{tabular}{lll}
\hline Level & Frequency & Percentage \\
\hline Freshman & 0 & 0 \\
Sophomore & 0 & 0 \\
Junior & 11 & $10 \%$ \\
Senior & 104 & $90 \%$ \\
Total & 115 & $100 \%$ \\
Major & & \\
MIS & 39 & $34 \%$ \\
HR & 56 & $49 \%$ \\
ACCT & 20 & $17 \%$ \\
Total & 115 & $100 \%$ \\
Experience of simulation-based game use \\
Yes & 50 & $43 \%$ \\
No & 65 & $57 \%$ \\
Total & 115 & $100 \%$ \\
\hline
\end{tabular}

\subsection{Assessment of the Measurement Model}

To analyze and test the reliability and validity of the proposed model, all factors have been categorized into two measurements: reflective and formative. Reflective measures contain both convergent and discriminant validity analysis. Convergent validity analysis was conducted to ensure that all constructs were related to each other. Factor loadings, composite reliability (CR), and average variance extracted (AVE) were used to test the convergence validity. According to Table 4, all reflective items had factor loadings that were higher than 0.7, which is the recommended value. CR values ranged from $0.894-0.938$, which exceeded the recommended value of 0.7. AVE was in the range of 0.68-0.791, which exceeded the recommended value of 0.5. After testing convergent validity, discriminant validity was next to be tested to ensure that the constructs were unique and not overlapping with each other. As per Table 5, all constructs belonged best with their predictor constructs that were assigned as per the model.

Table 4. Reflective and formative measures

\begin{tabular}{|c|c|c|c|c|}
\hline Item & Scale Type & Loading/ Weights* & AVE/ T-value* & CR/VIF* \\
\hline PE1 & Reflective & 0.91 & 0.791 & 0.938 \\
\hline PE2 & & 0.925 & & \\
\hline PE3 & & 0.839 & & \\
\hline PE4 & & 0.881 & & \\
\hline EE1 & Reflective & 0.812 & 0.689 & 0.898 \\
\hline EE2 & & 0.784 & & \\
\hline EE3 & & 0.875 & & \\
\hline EE4 & & 0.846 & & \\
\hline SI1 & Reflective & 0.829 & 0.68 & 0.894 \\
\hline SI2 & & 0.718 & & \\
\hline SI3 & & 0.868 & & \\
\hline SI4 & & 0.874 & & \\
\hline FC1 & Formative & 0.456 & 3.456 & 1.397 \\
\hline FC2 & & 0.231 & & 1.62 \\
\hline FC3 & & 0.511 & & 1.619 \\
\hline FC4 & & 0.04 & & 1.358 \\
\hline BI1 & Reflective & 0.856 & 0.734 & 0.932 \\
\hline BI2 & & 0.905 & & \\
\hline BI3 & & 0.92 & & \\
\hline BI4 & & 0.834 & & \\
\hline BI5 & & 0.758 & & \\
\hline UB1 & Reflective & 0.829 & 0.775 & 0.911 \\
\hline UB2 & & 0.913 & & \\
\hline UB3 & & 0.896 & & \\
\hline
\end{tabular}

Note. *Loadings, AVE, CR belong to the reflective measurement model. Weights, T-values, VIF belong to the formative measurement model. 
To validate the formative measures, the variance inflation factor (VIF) and weights were tested. VIF was used to diagnose collinearity/multicollinearity, which means assessing the redundancy among predictor constructs. Weight assessment was conducted to check if the measures were significant. As Table 4 illustrates, all weights' values were higher than the required value of 0.1 , except for one item; however, the authors did not remove it. Thereafter, VIF values were assessed to be less than 5. The authors found that all VIF values were accepted that ranged from 1.358-1.620. As such, the authors did not delete the item with the low weight.

Table 5. Inter-construct correlation

\begin{tabular}{lllllll}
\hline & BI & EE & FC & PE & SI & UB \\
\hline BI & $\mathbf{0 . 8 5 6}$ & & & & & \\
EE & 0.675 & $\mathbf{0 . 8 3 0}$ & & & & \\
FC & 0.789 & 0.719 & & & & \\
PE & 0.746 & 0.727 & $\mathbf{0 . 7 6 1}$ & $\mathbf{0 . 8 8 9}$ & & \\
SI & 0.715 & 0.648 & 0.659 & 0.796 & $\mathbf{0 . 8 2 4}$ & \\
UB & 0.723 & 0.537 & 0.715 & 0.738 & 0.659 & $\mathbf{0 . 8 8 0}$ \\
\hline
\end{tabular}

\subsection{Assessment of the Structural Model}

Table 6. Summary of the structural model

\begin{tabular}{lllllll}
\hline H. & Description & Path Coefficient ( $\beta)$ & Std. Dev. & T-value & P-value & Results \\
\hline H1 & Performance Expectancy $\rightarrow$ Behavioral Intentions & 0.344 & 0.119 & 2.886 & 0.004 & Supported \\
H2 & Effort Expectancy $\rightarrow$ Behavioral Intentions & 0.241 & 0.101 & 2.373 & 0.018 & Supported \\
H3 & Social Influence $\rightarrow$ Behavioral Intentions & 0.286 & 0.088 & 3.239 & 0.001 & Supported \\
H4 & Facilitating Conditions $\rightarrow$ Use Behavior & 0.382 & 0.111 & 3.456 & 0.001 & Supported \\
H5 & Behavioral Intentions $\rightarrow$ Use Behavior & 0.422 & 0.107 & 3.933 & 0.000 & Supported \\
\hline
\end{tabular}

According to Table 6, all the hypotheses are supported for the following justifications. For the first hypothesis, through which the authors aimed to test the influence of students' PE for using simulation games on the intention to use said games, the results showed that PE positively affects students' intention to use these games $(\beta=0.344$, $\mathrm{p}<0.005$ ). Thus, hypothesis 1 is supported, which means students' intention to use the simulation games is enhanced when the game appears to be useful to them and increases their learning outcomes.

The second hypothesis is the influence of students' EE for using simulation games on the intention to use said games; the results showed that EE positively affects students' intention to use the games $(\beta=0.241, p<0.005)$. Thus, hypothesis 2 is supported, which means students' intention to use simulation games is enhanced when the game is easy and straightforward to use. The third hypothesis is the influence of students' SI on using simulation games on intentions to use these games; the results showed that SI positively affects students' intention to use the games $(\beta=0.286, \mathrm{p}<0.005)$. Thus, hypothesis 3 is supported, which means students' intentions to use the simulation games is enhanced when the students' colleagues or others important to them advise them to use the game. The fourth hypothesis is the influence of FC for using simulation games on students' use behavior; the results showed that FC positively affects students' use behavior of using said games $(\beta=0.382, p<0.005)$. Thus, hypothesis 4 is supported, which means students use the games when they have more FC (such as the necessary resources and knowledge). The fifth and final hypothesis is the influence of students' intentions to use simulation games on their UB; the results showed that students' intentions to use simulation games affects their UB ( $\beta=$ $0.422, \mathrm{p}<0.005)$. Thus, hypothesis 5 is supported, which means students use the game if they have more intentions toward doing so. 


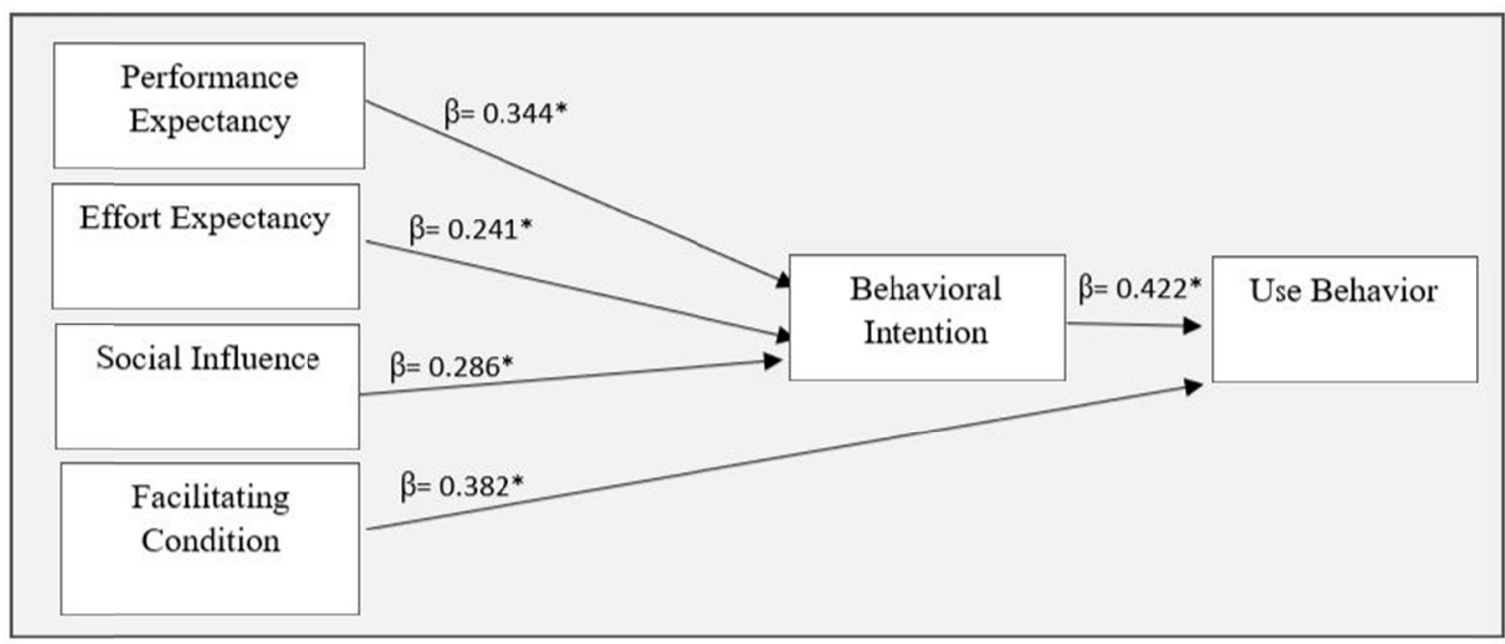

Figure 2. Results of the structural model

Note. ${ }^{*} \mathrm{p}<0.005$.

\subsection{Discussion of Findings}

Technology acceptance research history has revealed different results over the past 2.5 decades. Some results of previous studies are compatible with what the original authors proposed, while some other results conflict with their statements (Attuquayefio \& Addo, 2014). The focus of this study is to identify the factors that affect students' acceptance and use of simulation games as a new way of learning. As illustrated in the previous sections, the authors conducted a survey to support the model that was utilized to answer the research questions, and the results were summarized in five points.

First, there was a significant relationship between PE and BI. If the simulation game appears to be useful to the students and increases their learning outcomes, then their intentions to use the game will increase. This finding is consistent with previous SBL acceptance literature such as Lu and Lin (2012) study, which indicated the usefulness of simulation games is one of the core factors for students' use intention in computer networking education. Second, there was a significant relationship between EE and BI. It means if the simulation game appears to be easy and simple to use, students' intentions to use the game will increase. This finding is parallel to Lau and Woods (2009) study which revealed that the difficulty/ease level of using new leaning objects was a significant determinant for students' behavioral intention to use them. Third, there was a significant relationship between SI and BI. Meaning, if students' peers or others important to them advise using the simulation game, then students' intentions to use the game will increase. This relationship was also reported as positively significant by Hsu and Lu (2004) and Morgan (2000). Fourth, there was a significant relationship between FC and UB, which means if students have more FC (such as the necessary resources and knowledge), then the students will use the game. This finding is in line with Hwang (2019) study which highlighted that effective implementation of such games in learning requires instructor/teacher support that included providing recorded lectures, helpful materials, and descriptive and on-time responses to students' questions and technical problems. Fifth and last, there was a significant relationship between BI and UB. This leads the authors to conclude that if students have more intentions toward using the simulation game, then they will use the game. This go hand in hand with SPL acceptance literature for example (Lau \& Woods, 2009) and (Lemay et al., 2018).

Based on the survey results and findings of the hypotheses assessment, the authors provide the following recommendations

- First, based on the hypothesis 1 result, the instructor is recommended to explain how the simulation game will enhance the students' learning outcomes and how it will benefit them in their learning journey. Holding orientation sessions that demonstrate more about the simulation game will be highly beneficial to students. As a result, the students' intentions to use the game will be enhanced.

- Second, based on the hypothesis 2 result, the instructor is recommended to select a simulation game that fits the course learning outcomes and the students' learning level. As a result, the students' intentions to use the game will be improved.

- Third, based on the hypothesis 3 result, the instructor may host some students who played the 
simulation game previously to influence the students and improve their intentions to play the game.

- Fourth, based on the hypothesis 4 result, the college is recommended to provide the students with the necessary resources, such as simulation game guides, user manuals, and demonstration videos, while giving the instructors the needed training before starting the course.

- Fifth, based on the hypothesis 5 result, if the previous recommendations have been applied, the students will have more intentions toward using the simulation game.

- The study also revealed it is essential to provide appropriate training to students as well as teachers because the simulation game is considered a new way of learning.

\section{Conclusion}

In this study the authors applied the UTAUT model to find the factors that influence the students' acceptance of simulation games in the education sector, more specifically in management courses. Based on the findings and data analysis, it can be concluded that PE, EE, SI, and FC have positive influences on students' intention to use simulation games. In addition, there is a positive effect between BI and UB. The study has confirmed the validity of the UTAUT model in the field of simulation-based learning (game-based learning). This study also has impacts on the development and application of simulation games in terms of making them more efficient and effective in the education sector. Ultimately, different findings can be revealed using the same model in different environments.

This study has several limitations. First, it was applied to a limited number of students (115 students) only at one university. Second, the authors did not consider the effect of the moderating variables contained in the original UTAUT model. Finally, this study can be viable for any college, university, or any other institution; however, the authors cannot confirm that the results will be similar.

For future works, the authors recommend that researchers take into consideration the moderating variables while including students from other universities and increasing the sample size for more reliable research results. It is also suggested to employ a variety of different methods for collecting data to gain more responses, such as interviews and observations. Future researchers could investigate the change of students' attitudes toward simulation-based learning acceptance over a few years; the effects of more constructs on students' acceptance behavior such as trust, habit, and system quality; and so on.

\section{References}

Adobor, H., \& Daneshfar, A. (2006). Management simulations: Determining their effectiveness. Journal of Management Development, 25(2), 1151-1168. https://doi.org/10.1108/02621710610645135

Agarwal, R., \& Prasad, J. (1997). The role of innovation characteristics and perceived voluntariness in the acceptance of information technologies. Decision Sciences, 28(3), 557-582. https://doi.org/10.1111/j.1540-5915.1997.tb01322.x

Ajzen, I. (1991). The Theory of Planned Behavior. Organizational Behavior and Human Decision Processes, 50(2), 179-211. https://doi.org/10.1016/0749-5978(91)90020-T

Al-Juda, M. (2017). Distance learning students' evaluation of e-learning system in University of Tabuk, Saudi Arabia. Journal of Education and Learning, 6(4), 324-335. https://doi.org/10.5539/jel.v6n4p324

Anderson, T. (2016). Theories for learning with emerging technologies. In G. Veletsianos (Ed.), Emergence and innovation in digital learning: Foundations and applications (pp. 35-50). Edmonton, AB: Athabasca University Press.

Aranda, D. A. (2007). Simulating reality for teaching strategic management. Innovations in Education and Teaching International, 44(3), 273-386. https://doi.org/10.1080/14703290701486662

Attuquayefio, S., \& Addo, H. (2014). Using the UTAUT model to analyze students' ICT adoption. International Journal of Education and Development Using Information and Communication Technology (IJEDICT), 10, 75-86. Retrieved from https://files.eric.ed.gov/fulltext/EJ1059042.pdf

Bandura, A. (1978). The self-system in reciprocal determinism. American Psychologist, 33, 344-358. https://doi.org/10.1037/0003-066X.33.4.344

Bandura, A. (1986). Prentice-Hall series in social learning theory. Social foundations of thought and action: A social cognitive theory. Englewood Cliffs, NJ, US: Prentice-Hall, Inc.

Bandura, A. (1989). Social cognitive theory. In R. Vasta (Ed.), Annals of child development (Vol. 6. Six theories 
of child development, pp. 1-60). Greenwich, CT: JAI Press.

Bell, B. S., \& Federman, J. E. (2013). E-learning in postsecondary education. The Future of Children, 23(1), 165-185. https://doi.org/10.1353/foc.2013.0007

Bell, B. S., Kanar, A. M., \& Kozlowski, S. W. J. (2008). Current issues and future directions in simulation-based training in North America. The International Journal of Human Resource Management, 19(8), 1416-1434. https://doi.org/10.1080/09585190802200173

Binkley, M., Erstad, O., Herman, J., Ripley, M., Miller-Ricci, M., \& Rumble, M. (2012). Defining twenty-first century skills. In P. Griffin, B. McGaw \& E. Care (Eds.), Assessment and teaching of 21 st century skills (pp. 17-66). Dordrecht: Springer. https://doi.org/10.1007/978-94-007-2324-5_2

Bowers, C., \& Cannon-Bowers, J. (2009). Synthetic learning environments: On developing a science of simulation, games, and virtual worlds for training. In Learning, training, and development in organizations (pp. 250-282). Routledge.

Capsim.com. (2017). About Capsim. Retrieved from https://capsim.com/about/\#/about

Compeau, D. R., \& Higgins, C. A. (1995). Computer self-efficacy: Development of a measure and initial test. MIS Quarterly, 19, 189-211. https://doi.org/10.2307/249688

Cooper, J., \& Mueck, R. (1990). Student involvement in learning: Cooperative learning and college instruction. Journal on Excellence in College Teaching, 1, 68-76.

Costin, Y., O'Brien, M., \& Slattery, D. (2018). Using simulation to develop entrepreneurial skills and mind-set: An exploratory case study. International Journal of Teaching and Learning in Higher Education, 30(1), 136-145. Retrieved from https://files.eric.ed.gov/fulltext/EJ1169805.pdf

Dale, A. G., \& Klasson, C. R. (1962). Business gaming: A survey of American collegiate schools of business. Austin: University of Texas Bureau of Business Research.

Davis, F. D. (1989). Perceived usefulness, perceived ease of use, and user acceptance of information technology. MIS Quarterly, 13(3), 319-340. https://doi.org/10.2307/249008

Davis, F. D., Bagozzi, R. P., \& Warshaw, P. R. (1989). User acceptance of computer technology: A comparison of two theoretical models. Management Science, 35(8), 982-1003. https://doi.org/10.1287/mnsc.35.8.982

Davis, F. D., Bagozzi, R. P., \& Warshaw, P. R. (1992). Extrinsic and intrinsic motivation to use computers in the workplace. Journal of Applied Social Psychology, 22(14), 1111-1132. https://doi.org/10.1111/j.1559-1816.1992.tb00945.x

Faizan, N. D., Löffler, A., Heininger, R., Utesch, M., \& Krcmar, H. (2015). Classification of evaluation methods for the effective assessment of simulation games: Results from a literature review. International Journal of Engineering Pedagogy.

Faria, A. J. (1998). Business simulation games: Current usage levels — an update. Simulation and Gaming, 29(3), 295-308. https://doi.org/10.1177/1046878198293002

Faria, A. J., \& Nulsen, R. O. (2014). Business simulation games: Current usage levels. A ten-year update. Developments in Business Simulation and Experiential Learning: Proceedings of the Annual ABSEL Conference. Retrieved from https://absel-ojs-ttu.tdl.org/absel/index.php/absel/article/view/1156/1125

Faria, A. J., \& Wellington, W. J. (2004). A survey of simulation game users, former users and never users. Simulation and Gaming, 35(2), 178-207. https://doi.org/10.1177/1046878104263543

Feinstein, A. H., Mann, S., \& Corsun, D. L. (2002). Charting the experiential territory: Clarifying definitions and uses of computer simulation games and role play. Journal of Management Development, 21(10), 732-744. https://doi.org/10.1108/02621710210448011

Fischer, H., Heise, L., Heinz, M., Moebius, K., \& Koehler, T. (2014). E-learning trends and hypes in academic teaching. Methodology and Findings of a Trend Study. Retrieved from https://files.eric.ed.gov/fulltext/ED557279.pdf

Fishbein, M., \& Ajzen, I. (1975). Belief, attitude, intention and behavior: An introduction to theory and research. Reading, MA: Addision-Wasely.

Gaba, D. M. (2004). The future vision of simulation in health care. Quality \& Safety in Health Care, 13(Suppl 1), i2-10. https://doi.org/10.1136/qhc.13.suppl_1.i2 
Garris, R., Ahlers, R., \& Driskell, J. E. (2002). Games, motivation, and learning: A research and practice model. Simulation \& Gaming, 33(4), 441-467. https://doi.org/10.1177/1046878102238607

Gredler, M. (2004). Games and simulations and their relationships to learning. In D. H. Jonassen (Ed.), Handbook of research on educational communications and technology (pp. 571-581). Mahwah, NJ, US: Lawrence Erlbaum Associates Publishers.

Halili, S., Sulaiman, H., \& Abdul, R. R. (2017). Information and communications technology acceptance among Malaysian adolescents in urban poverty. TOJET: The Turkish Online Journal of Educational Technology, 16(1), 47-54. Retrieved from https://files.eric.ed.gov/fulltext/EJ1124921.pdf

Hsu, E. (1989). Role-event gaming simulation in management education: A conceptual framework and review. Simulation \& Games, 20(4), 409-438. https://doi.org/10.1177/104687818902000402

Hsu, C.-L., \& Lu, H.-P. (2004). Why do people play on-line games? An extended TAM with social influences and flow experience. Information \& Management, 41(7), 853-868. https://doi.org/10.1016/j.im.2003.08.014

Hwang, M. (2019). ERP Simulation Games in Asynchronous Online Classes. e-Journal of Business Education \& Scholarship of Teaching, 13(3), 37-45.

Kim, Y. J., \& Shute, V. J. (2015). The interplay of game elements with psychometric qualities, learning, and enjoyment in game-based assessment. Computers \& Education, 87, 340-356. https://doi.org/10.1016/j.compedu.2015.07.009

Koparan, T., \& Yilmaz, G. K. (2015). The effect of simulation-based learning on prospective teachers' inference skills in teaching probability. Universal Journal of Educational Research, 3(11), 775-786. https://doi.org/10.13189/ujer.2015.031101

Koppenhaver, G. D. (1993). An evaluation of three bank management simulations: Preliminary results. Financial Practice and Education, 3(2), 89-96.

Lali, A. (2008). Play the Innov8 game to learn business process management. Retrieved from https://www.ibm.com/developerworks/library/ws-bpm-innov8/ws-bpm-innov8-pdf.pdf

Lateef, F. (2010). Simulation-based learning: Just like the real thing. Journal of Emergencies, Trauma, and Shock, 3(4), 348. https://doi.org/10.4103/0974-2700.70743

Lau, S.-H., \& Woods, P. C. (2009). Understanding learner acceptance of learning objects: The roles of learning object characteristics and individual differences. British Journal of Educational Technology, 40(6), 10591075. https://doi.org/10.1111/j.1467-8535.2008.00893.x

Laurillard, D. (2007). Modelling benefits-oriented costs for technology enhanced learning. Higher Education, 54(1), 21-39. https://doi.org/10.1007/s10734-006-9044-2

Lean, J., Moizer, J., Towler, M., \& Abbey, C. (2006). Simulations and games: Use and barriers in higher education. Active Learning in Higher Education, $227-242$. https://doi.org/10.1177/1469787406069056

Lemay, D. et al. (2018). Modeling Students Perceptions of Simulation-Based Learning Using the Technology Acceptance Model. Clinical Simulation in Nursing, 20, 28-37. https://doi.org/10.1016/j.ecns.2018.04.004

Li, J., \& Dong, P. (2009). Simulation-based e-learning system for management decision and its effect: A case study in MBA teaching (pp. 694-699). IEEE International Symposium on IT in Medicine \& Education. https://doi.org/10.1109/ITIME.2009.5236334

Liang, C., Lee, Y. Z., \& Chou, W. S. (2010). The design consideration for game-based learning. Educational Technology, 50(2), 25-28.

Lin, T. C., \& Huang, C. C. (2008). Understanding knowledge management system usage antecedents: An integration of social cognitive theory and task technology fit. Information \& Management, 45(6), 410-417. https://doi.org/10.1016/j.im.2008.06.004

Lu, H.-K., \& Lin, P.-C. (2012). Effects of interactivity on students' intention to use simulation-based learning tool in computer networking education (pp. 573-576). 14th International Conference on Advanced Communication Technology (ICACT).

MacKay, R. B., \& McKiernan, P. (2004). Exploring strategy context with foresight. European Management Review, 1(1), 69-77. https://doi.org/10.1057/palgrave.emr.1500010

Mădălina, E., Dedu, M., \& Deaconu, A. (2017). The use of information and communication technology (ICT) as 
a teaching method in vocational education and training in tourism. Acta Didactica Napocensia, 10(3), 1934. https://doi.org/10.24193/adn.10.3.2

Mann, B. D., Eidelson, B. M., Fukuchi, S. G., Nissman, S. A., Robertson, S., \& Jardines, L. (2002). The development of an interactive game-based tool for learning surgical management algorithms via computer. The American Journal of Surgery, 183(3), 305-308. https://doi.org/10.1016/S0002-9610(02)00800-0

Mathieson, K. (1991). Predicting user intentions: Comparing the technology acceptance model with the theory of planned behavior. Information Systems Research, 2(3), 173-191. https://doi.org/10.1287/isre.2.3.173

Moore, G. C., \& Benbasat, I. (1991). Development of an Instrument to Measure the Perceptions of Adopting an Information Technology Innovation. Information Systems Research, 2(3), 192-222. https://doi.org/10.1287/isre.2.3.192

Morgan, K. (2000). Cross-Cultural Considerations for Simulation-Based Learning Environments. Simulation \& Gaming, 31(4), 491-508. https://doi.org/10.1177/104687810003100404

Practice Operations. (n.d.). Retrieved from https://www.mhpractice.com/products/Practice_Operations

Prensky, M., \& Prensky, M. (2007). Digital game-based learning (Vol. 1). St. Paul, MN: Paragon House. https://doi.org/10.1145/950566.950596

Rogers, E. M. (1995). Diffusion of innovations (4th ed.). New York, NY: Free Press.

Roodt, S., \& Joubert, P. (2009). Evaluating serious games in higher education: A theory-based evaluation of IBMs Innov8 (pp. 332-338). In Proceedings of the 3rd European Conference on Games-based learning, Academic Publishing Limited.

Ruiz, J. G., Mintzer, M. J., \& Leipzig, R. M. (2006). The impact of e-learning in medical education. Academic Medicine, 81(3), 207-212. https://doi.org/10.1097/00001888-200603000-00002

Salas, E., Wildman, J. L., \& Piccolo, R. F. (2009). Using simulation-based training to enhance management education. Academy of Management Learning \& Education, 8(4), 559-573. https://doi.org/10.5465/AMLE.2009.47785474

Sharma, R., \& Mishra, R. (2014). A review of evolution of theories and models of technology adoption. Retrieved

from https://www.researchgate.net/profile/Rajesh_Sharma80/publication/295461133_A_Review_of_Evolution_o f_Theories_and_Models_of_Technology_Adoption/links/56caalea08ae5488fōj94ea7.pdf

Swanson, E. B. (1974). Management information systems: Appreciation and involvement. Management Science, 21(2), 178-188. https://doi.org/10.1287/mnsc.21.2.178

Tan, P. J. (2013). Applying the UTAUT to understand factors affecting the use of English e-learning websites in Taiwan. SAGE Open, 3(4). https://doi.org/10.1177/2158244013503837

Taylor, S., \& Todd, P. A. (1995). Understanding information technology usage: A test of competing models. Information Systems Research, 6, 144-176. https://doi.org/10.1287/isre.6.2.144

Thompson, R., Higgins, C., \& Howell, J. (1991). Personal computing: Toward a conceptual model of utilization. MIS Quarterly, 15(1), 124-143. https://doi.org/10.2307/249443

Thrasher, R. G., Andrew, D. P. S., \& Mahony, D. F. (2007). The efficacy of a modified theory of reasoned action to explain gambling behavior in college students. Journal of Gambling Studies, 27(3), 499-516. https://doi.org/10.1007/s10899-010-9215-z

Vallerand, R. J. (1997). Toward a hierarchical model of intrinsic and extrinsic motivation. In M. Zanna (Ed.), Advances in experimental social psychology (pp. 271-360). New York: Academic Press. https://doi.org/10.1016/S0065-2601(08)60019-2

Venkatesh, V., \& Davis, F. D. (2000). A theoretical extension of the technology acceptance model: Four longitudinal studies. Management Science, 46, 186-204. https://doi.org/10.1287/mnsc.46.2.186.11926

Venkatesh, V., Morris, M., Davis, G., \& Davis, F. (2003). User acceptance of information technology: Toward a unified view. MIS Quarterly, 27, 425-478. https://doi.org/10.2307/30036540

Yeun, E. J., Bang, H. Y., Ryoo, E. N., \& Ha, E. H. (2014). Attitudes toward simulation-based learning in nursing students: An application of Q methodology. Nurse Education Today, 34(7), 1062-1068. https://doi.org/10.1016/j.nedt.2014.02.008 
Yusuf, N., \& Al-Banawi, N. (2013). The impact of changing technology: The case of e-learning. Contemporary Issues in Education Research (CIER), 6(2), 173. https://doi.org/10.19030/cier.v6i2.7726

\section{Copyrights}

Copyright for this article is retained by the author, with first publication rights granted to the journal.

This is an open-access article distributed under the terms and conditions of the Creative Commons Attribution license (http://creativecommons.org/licenses/by/4.0/). 